\title{
CORRECTION
}

\section{Correction to: Correspondence on "AminoacyltRNA synthetase deficiencies in search of common themes" by Fuchs et al.}

Yan-Wen Shen and Li-Ping Zou (iD)

Genetics in Medicine (2021) 23:2231; https://doi.org/10.1038/s41436-021-01160-7

Correction to: Genetics in Medicine (2021) 23:587-588; https://doi. org/10.1038/s41436-020-01013-9; Article published online 22 October 2020

The original version of this article unfortunately contained a mistake. Reference ${ }^{5}$ was incorrect. The corrected reference is given below. The original article has been corrected.

\section{REFERENCE}

5. Shen, Y. W. et al. QARS1 gene related glutaminyl-tRNA synthetase deficiency syndrome: report of three cases and a review of literature. Zhonghua Er Ke Za Zhi. 58, 1006-1012, https://doi.org/10.3760/cma.j.cn112140-20200603-00571 (2020). Chinese. PMID: 33256324.

\section{ADDITIONAL INFORMATION}

Correspondence and requests for materials should be addressed to L.P.Z.Z.

Reprints and permission information is available at http://www.nature.com/ reprints 